\title{
CRIME, CASTIGO E COTIDIANO NO SERTÃO ESCRAVISTA GUARAPUAVANO DURANTE A SEGUNDA METADE DOS OITOCENTOS
}

\author{
SLAVERY, CRIMINALITY AND PUNISHMENT IN \\ QUOTIDIAN BACKLANDS OF THE GUARAPUAVA \\ DURING THE SECOND HALF IN THE NINETEENTH \\ CENTURY
}

\section{Eliana Djubatie}

\begin{abstract}
RESUMO
Conferindo particular relevo aos episódios em que os cativos vitimaram seus próprios senhores, os pesquisadores da historiografia social da escravidão no Brasil tenderam a interpretá-los como formas de resistência dos escravos contra o cativeiro. Entretanto, nas regiões rurais onde predominavam as pequenas posses de escravos, novos estudos têm demonstrado que as circunstâncias de ocorrência dessas ações, muitas vezes, aproximavam os cativos mais do mundo dos homens livres do que de seus senhores. O presente estudo busca discutir tais desdobramentos historiográficos e apresentar algumas conclusões a respeito da análise de três eventos registrados pelas autoridades policiais na comarca de Guarapuava - uma região de senhores de poucos escravos - envolvendo livres e cativos no século XIX.
\end{abstract}

Palavras-chave: Escravidão. Criminalidade. Guarapuava.

\begin{abstract}
Conferring particular emphasis on episodes in which the captives victimized their own lords, researchers of slavery's social historiography in Brazil tended to interpret them as forms of resistance against the slave's captivity. Meanwhile, in areas where the small possessions of slaves were dominant, new studies have shown that the circumstances of the occurrence of such actions often approached the captive to the free man's world instead of their lords' universe. This study aims to discuss such historiographies developments and to present some conclusions about the analysis of three events recorded by the police authorities in the district of Guarapuava - a region of lords with a few slaves - involving slaves and freemen in the nineteenth century.
\end{abstract}

Keywords: Slavery. Criminality. Guarapuava. 
Perguntado por que motivo havia matado seu senhor Joaquim Pires Franco, respondeu que estando ambos no mato, seu senhor mandou-o procurar umas abelheiras e para esse fim deu-lhe duas horas, e como nas duas horas nada encontrou, seu senhor deu nele com o cabo da enxada e jurou-lhe que naquele dia o havia de castigar amarrado, e que de fato tendo ao por do sol prevenindo-se de duas cinchas de cavalgadura que ali estavam e esperava por ele réu, que se achava no serviço, para o amarrar e castigar; veio [José], lançou mão de um porrete que perto de si se achava e deu-lhe duas pancadas na cabeça com as quais o matou instantaneamente. E que além dessa razão existe ainda a de sempre andar com fome, pelo mau-trato que lhe dava seu Senhor, e que por causa disso há muito tempo antes já havia pedido a seu Senhor que o vendesse e que este lhe respondera que o mais fácil seria o diabo levar ele réu para o inferno do seu Senhor o vender. ${ }^{1}$

Estudar a escravidão em pequenas propriedades não é pensar uma escravidão branda ou acreditar que as condições de pobreza compartilhadas com o senhor favoreciam um contato harmonioso, distanciando os cativos de uma disciplina mais rígida. No caso descrito acima, tanto o senhor quanto o cativo vieram para Guarapuava saindo da região de Parati, na província do Rio de Janeiro, e, é provável que conhecessem formas de associação e de posicionamento hierárquico comuns a grupos maiores. Possivelmente, as teriam incorporado à dinâmica desse sistema que neutralizava as eventuais negociações mais comuns às pequenas posses. Nesse caso, não seria exagero afirmar - com base no que será descrito - que suas relações e percepções se equiparavam às da plantation.

A reocupação e o povoamento dos Campos de Guarapuava decorreram de um processo oficial determinado pelo governo, através da concessão de sesmarias. Esse processo foi iniciado definitivamente em 1809, com uma expedição que saiu de Curitiba. Já em meados do século XVIII havia o entendimento da necessidade de povoar a região, juntamente com Iguatemi e Tibagi, a fim de proteger a fronteira do sul do país das ameaças espanholas e desenvolvê-la economicamente. Montaram-se então milícias nas quais se incluíram, além de "homens de posse, aqueles que pudessem desempenhar bem suas funções na lavoura e na criação de gado, e, em possíveis confrontos, pudessem impor armas para a defesa territorial". ${ }^{2}$

Figura 1 - Rota da expedição de conquista de Guarapuava

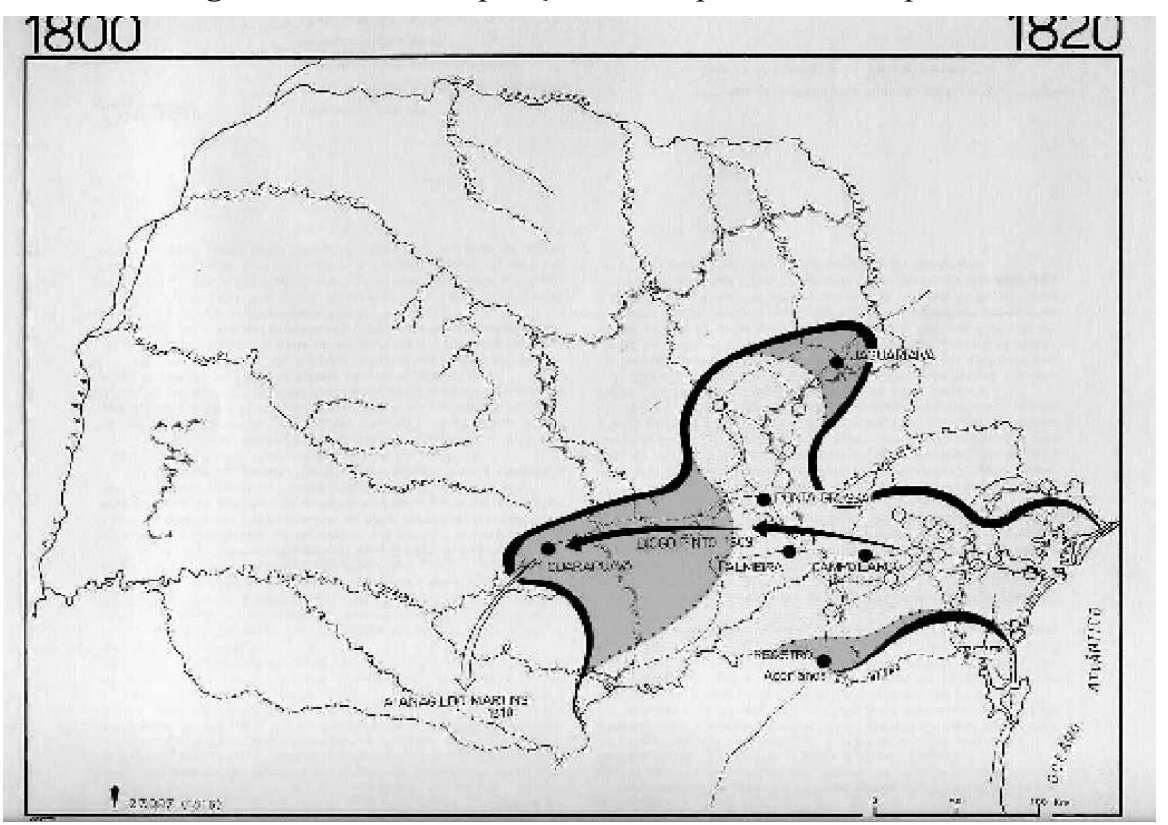

Fonte: Jayme Antonio Cardoso; Cecília Maria Westphalen. Atlas histórico do Paraná. 2. ed., ampl. Curitiba: Livraria do Chain, 1986.

\footnotetext{
Centro de Documentação e Memória/Guarapuava, Unicentro. Juízo de Direito da Comarca de Guarapuava, processo criminal oㅡ 866.2.79, caixa no 03,1866 a 1867 , folha 30 .
}

\footnotetext{
${ }^{2}$ Fernando Franco Netto. Povoamento, população e escravidão no século XIX. Guarapuava: Unicentro, 2007. p. 48.
} 
O território que compreendia Guarapuava, caracterizada como região-limite entre as Repúblicas do Prata e o Império do Brasil, foi durante a maior parte do século XIX voltado para a lavoura de alimentos, a criação e a comercialização de animais. Baseada numa economia interna, desenvolvida em torno do trabalho familiar, escravo e de agregados, promovia suporte necessário para outras áreas, voltadas ao comércio externo. ${ }^{3}$

A população escrava, composta predominantemente por crioulos ${ }^{4}$, cresceu gradativamente durante boa parte do século XIX. Os cativos contribuíram de maneira significativa com o processo de formação e consolidação das estruturas sociais, políticas e econômicas da região. Verifica-se que na primeira metade do século XIX a posse média na cidade de Guarapuava era de 3,1 cativos por proprietário, enquanto na segunda metade do século foi de 6,7, mas com sinais de redução a partir da década de 1870. "A hipótese para esse crescimento é o processo de fortalecimento, a partir da década de 1850 , não só das atividades ligadas à pecuária e à criação, mas certamente o movimento tropeiro que invade Guarapuava, principalmente após a abertura da estrada das missões." 5

Existia uma ligação direta entre o tamanho da propriedade, a dimensão da riqueza e o número

\footnotetext{
3 "A pecuária e a produção de erva-mate possibilitaram um entrelaçamento de rotas mercantis ligadas tanto às Repúblicas do Prata como a São Paulo e Rio de Janeiro. O que tornou o ambiente de nova colonização, além de último ponto de alocação de livres pobres, lugar de ressonância de tensões existentes em outros espaços da organização social e econômica." Rosângela Ferreira Leite. Nos limites da colonização: ocupação territorial, organização econômica e populações livres pobres (Guarapuava 1808-1878). Tese de doutorado em história. São Paulo: Universidade de São Paulo, 2006. p. 19.

${ }^{4}$ A etnicidade e a classificação social tem gerado discussões na historiografia atual. Atentando para esses debates relacionados às representações identitárias do passado para designar africanos e seus descendentes, Douglas Cole Libby e Zephyr Frank apresentam uma discussão conveniente acerca da terminologia "crioulo" no período que se estende de 1780 a $1810 \mathrm{em}$ São José do Rio das Mortes, em Minas Gerais. Os autores apontam que na América portuguesa a etnicidade se pautava em questões de naturalidade, entrelaçada por posição social, mas que esses entrecruzamentos ainda não estão totalmente entendíveis pela historiografia. Apontam ainda que há consenso entre os especialistas de que os filhos de escravas africanas eram designados como crioulos (1ª geração), mas não quanto à classificação daqueles de descendência além da segunda geração. Por outro lado, Libby e Frank identificaram que em Minas a definição de crioulo referia-se aos negros nascidos no Brasil, independentemente da origem dos pais africana, nativa ou ambas —, demonstrando a flexibilidade de designação conforme o lugar de inserção dos africanos e seus descendentes. (Douglas Cole Libby; Zephyr Frank. "Voltando aos registros paróquias ["registros das paróquias"?; "registros paroquiais"?] de Minas colonial: etnicidade em São José do Rio das Mortes, 1780-1810". Revista Brasileira de História, São Paulo, v. 29, n 58 (2009). p. 383-415

${ }^{5}$ Franco Netto, cit., p. 268.
}

de cativos. Em Guarapuava, as posses de escravos eram sempre pequenas, além de figurarem como um privilégio de poucos domicílios. Os dados computados por Franco Netto mostram que em 1835 apenas $29 \%$ dos domicílios podiam contar com esse tipo de mão de obra; porém, como o próprio autor considera, esse é um número relativamente grande se comparado ao Paraná, onde a média era de $19 \%{ }^{6}$ As propriedades que possuíam maior número de cativos eram aquelas em que a população escrava tinha idade inferior a 10 anos - presentes mais fortemente no início do século XIX. Em contrapartida, os domicílios que possuíam menos escravos podiam contar com uma população deles consideravelmente mais velha. ${ }^{7}$

Considerando essa conjuntura de economia de subsistência de Campos de Guarapuava em fins do século XIX, e a finalidade de aprofundar as compreensões das relações cotidianas existentes nessa localidade à luz da historiografia social da escravidão, fundamentada em fontes judiciais, foi realizado um levantamento, no Centro de Documentação e Memória de Guarapuava, dos processos criminais e autos policiais envolvendo livres e cativos no período que se estende de 1860 a 1888; destes, foram selecionados, para fins de estudos, três eventos registrados pelas autoridades policiais na comarca. $\mathrm{O}$ critério utilizado para a seleção dos casos foi baseado na construção de uma amostra dos tipos de ações registradas no local e que, ao mesmo tempo, pudesse evidenciar o caráter multifacetado do sistema escravista, presente nos mais distantes sertões do Império do Brasil. Acredito que essas fontes permitirão compreender parte do cotidiano escravista, enfocando de modo peculiar as relações entre livres e cativos em ambientes e casos ora comuns, ora distintos dos já apresentados pela historiografia brasileira.

O auto criminal é um material singular, por captar, registrar as nuanças e tensões sociais que envolveram várias regiões subordinadas ao regime de trabalho escravo. Mostram-se valiosos para a análise dos crimes, dos seus mecanismos impulsionadores, e possibilitam reconstituições da vida social. Apontam ainda para possíveis significados

\footnotetext{
${ }^{6}$ Horácio Gutiérez. "Donos de terras e escravos no Paraná: padrões e hierarquias nas primeiras décadas do século XIX”. História, São Paulo, 25, (2006). p. 100-122.

${ }^{7}$ Franco Netto, cit., passim.
} 
que dela fizeram os sujeitos envolvidos em situações tidas como infratoras. ${ }^{8}$

Vale lembrar que assim como outros tipos de documentos submetidos à crítica de historiadores, os autos criminais também possuem limitações, e a escrita da história, como adverte Michel de Certeau, constrói-se a partir de uma instituição e obedece a regras próprias que exigem considerações. ${ }^{9}$ Dessa forma, os autos criminais serão analisados, neste trabalho, tomando em conta as obras de Edward Palmer Thompson, há muito frequentadas pelos historiadores brasileiros. Para o autor, a lei deve ser encarada como uma expressão histórica compreensível apenas no confronto com os aspectos da totalidade da sociedade na qual está inserida. Como um campo de constantes embates, a lei pode, simultaneamente, alterar comportamento dos poderosos e mistificar os destituídos do poder. ${ }^{10}$

Para Ivan de Andrade Vellasco, os indivíduos pobres, livres e escravos, não foram totalmente ignorados pelo aparato judicial (manipulado e dominado pela elite), como sugerem alguns estudiosos, mas fizeram uso do poder judiciário para negociar a ordem e afirmar suas visões de justiça e liberdade. Dessa maneira, mostraram estar atentos a determinadas ações do poder, interpretando da maneira que lhes era conveniente a justiça e a função dos seus funcionários. ${ }^{11}$ Com a proposta de compreender as experiências de populações cativas nas fontes judiciais é fundamental também perceber que os processos criminais e os autos policiais são documentos burocráticos, cuja função é procurar pistas, indagar e registrar os relatos comuns às fontes judiciais, sejam eles a respeito de réus, vítimas ou testemunhas. Segundo Silvia Lara, essas fontes permitem uma aproximação da fala do escravo, porém é preciso estar atento aos filtros pelos quais passam os depoimentos, ou seja, é necessário considerar os agentes sociais envolvidos, como o escrivão. ${ }^{12}$

\footnotetext{
${ }^{8}$ Maria de Fátima Novaes Pires. O crime na cor: escravos e forros no alto sertão da Bahia (1830-1888). São Paulo: Annablume/Fapesp, 2003. p. 22.

${ }^{9}$ Michel de Certeau. A escrita da história. 2. ed. Rio de Janeiro: Forense, 2002.

${ }^{10}$ Edward Palmer Thompson. Senhores e caçadores: a origem da Lei Negra. Rio de Janeiro: Paz e Terra, 1987.

${ }^{11}$ Ivan de Andrade Vellasco. As seduções da ordem: violência, criminalidade e administração da justiça: Minas Gerais, século 19. São Paulo: Edusc, 2004.

12 Silvia Hunold Lara. Campos da violência: escravos e senhores na capitania do Rio de Janeiro, 1750-1808. Rio de Janeiro: Paz e Terra, 1988.
}

Se os processos trazem manifestações diversas, atendendo aos interesses dos grupos dominantes ou impondo restrições às ações destes, cabe ao pesquisador estabelecer uma relação cuidadosa e criteriosa com essas fontes, de maneira que se possa extrair delas o máximo possível de informações que permitam interpretações de como a justiça criminal narra às pessoas envolvidas. Segundo João José Reis, "um documento vale naturalmente apenas pelo que diz, mas também por suas ausências e por seus silêncios" ${ }^{13}$ E é através dessas observações que se torna possível identificar e compreender o complexo cotidiano dos agentes envolvidos, passível de lutas e conflitos que se apresentam de diferentes formas nesses documentos.

Os autos policiais e processos criminais figuram, sem dúvida, como fontes fundamentais nas investigações historiográficas interessadas na interpretação das manifestações dos agentes envolvidos - ora como protagonistas, ora como peças de um contexto mais amplo. Para a região de Guarapuava é oportuno lançar mão dessas fontes para contribuir com a compreensão das tensões e dos conflitos que envolveram os cativos no cotidiano.

\section{Retomando o caso...}

José, escravo do senhor Joaquim Pires Franco, trinta anos mais ou menos, solteiro, natural de Parati, província do Rio de Janeiro, residente no distrito de Guarapuava, não sabe ler nem escrever. Tão comum como seus dados pessoais também é a qualificação do crime nas abordagens historiográficas, desde as primeiras análises feitas por pesquisadores que utilizaram das fontes jurídico-policiais e que enquadraram as ações escravas como reflexo do estado de inconformismo em relação ao sistema escravista. Para Wissenbach, muitos crimes assemelhavam-se entre si e mostravam as contradições desse sistema. ${ }^{14}$

Maria Cristina Cortez Wissenbach tratou do assunto no livro Sonhos africanos, vivências ladinas. Sobre a história de escravos e forros em São Paulo no período de 1850 a 1880 , a autora concluiu que na região estudada por ela, onde predominavam

\footnotetext{
${ }^{13}$ João José Reis; Eduardo Silva. Negociação e conflito: a resistência negra no Brasil escravista. São Paulo: Companhia das Letras, 1996. p. 67.

${ }^{14}$ Maria Cristina Cortez Wissenbach. Sonhos africanos, vivências ladina: escravos e forros em São Paulo (1850-1880). São Paulo: Hucitec, 1998.
} 
senhores remediados ou pobres, a resistência escrava em todas as suas manifestações - fugas, assassinatos, suicídio, rebeliões e formação de quilombos - apresentava o repúdio ao regime escravista e a própria condição de cativo, mas que, acima de tudo, tais manifestações configuravam-se como estratégias de sobrevivência cotidiana. ${ }^{15}$

Maria Helena Machado, em Crime e escravidão, obra baseada em estudos de processos criminais de escravos da região de Taubaté e Campinas, registrados entre 1830 e 1888, aborda desde o momento da hegemonia da dominação escravista até o processo de desagregação do cativeiro. A autora aponta algumas estratégias de luta do escravo contra o cativeiro, tais como resistência ao ritmo de trabalho e exigências crescentes em relação aos direitos de tempo e espaço autônomo no interior da fazenda. Tais práticas procuravam colocar limite à exploração escravista. Essas ações, identificadas muitas vezes como crimes pelas autoridades, ocorriam de forma consciente, com o intuito de forjar espaços de sobrevivência e até mesmo de buscar a liberdade. ${ }^{16}$

Como observamos, alguns autores apresentam os atos considerados crimes pela justiça como ações individuais de luta contra o cativeiro. ${ }^{17} \mathrm{Ou}$ tros, como Alysson Freitas de Jesus, em estudos acerca do sertão de Minas, mostram que a violência em muitos casos está mais ligada à resolução de "pendengas". ${ }^{18}$ Porém, estou certa de que não foram esses os casos no que se refere ao processo analisado. Muitas vezes, a maioria dos cativos não possuía uma "compreensão da escravidão em sua amplitude institucional". ${ }^{19}$ Sendo assim, acredito que José tenha sido realmente motivado pela revolta contra seu proprietário e o modelo de cativeiro tido como aceitável. Nem pendenga, nem resistência para desestabilizar o sistema.

Atitudes isoladas como essas refletem fins que beneficiam apenas interesses individuais; não

\footnotetext{
${ }^{15}$ Id. Ibid.

${ }^{16}$ Maria Helena P. T. Machado. Crime e escravidão: trabalho, luta e resistência nas lavouras paulistas (1830-1888). São Paulo: Brasiliense, 1987.

${ }^{17}$ Cf., entre outros, Reis e Silva, Negociação e conflito; Machado, Crime e escravidão; Lara, Campos da violência; Chalhoub, Visões da liberdade.

${ }^{18}$ Alysson Luiz Freitas de Jesus. No sertão das Minas: escravidão, violência e liberdade (1830-1888). São Paulo: Annablume; Belo Horizonte: Fapemig, 2007.

${ }^{19}$ Ricardo Alexandre Ferreira. Crimes em comum: escravidão e liberdade no extremo nordeste da província de São Paulo (Franca, 1830-1888). Tese de doutorado em História. Franca: Faculdade de História, Direito e Serviço Social, 2006. p. 12.
}

há um sentimento de coletividade que vise um bem comum. Quando José assassina seu senhor, não intenciona a liberdade de seus companheiros da crueldade e da arrogância senhorial, mas é movido pela raiva e o desejo único de livrar-se dos castigos que eram considerados injustos e cruéis. Para João José Reis, cada escravo concebia de maneira bem definida o que seria uma dominação aceitável, baseado em costumes e conquistas individuais alcançados no cotidiano de suas relações. ${ }^{20}$

A legitimação do cativeiro foi tema de pesquisa abordado por Sidney Chalhoub em Visões $d a$ liberdade. Por meio da interpretação de vários processos cíveis, nos quais os cativos lutavam por liberdade, o autor lança argumentos a fim de desconstruir a ideia de escravo-coisa - aquele que é incapaz de ação autônoma - e ainda enfatiza a existência de laços de solidariedade entre os cativos. Mostra que eles nem sempre compreendiam a liberdade como a formação de quilombos, mas que as visões de liberdade iam além, identificadas em outras formas, que possibilitassem alcançar autonomia dentro da instituição. Os cativos não eram coisas sem consciência, eram sujeitos de sua própria história. ${ }^{21}$ Ademais, para o autor, as menções aos castigos intoleráveis permitem-nos acessar "todo um universo de percepção dos escravos a respeito de seus direitos, percepções essas que fundamentavam ações firmes no sentido de impor certos limites à ciranda de negócios da escravidão". ${ }^{22}$

Nesse sentido, o cativeiro quase sempre era efetivado pelo poder de dominação dos senhores que possuíam grande liberdade de ação sobre seus escravos. "Mas, mesmo que o castigo de escravos fosse um direito dos senhores, quase uma obrigação socialmente reconhecida e legalizada, este castigo deveria ser entendido como justo." ${ }^{23}$

Embora o castigo fosse um direito legalmente reconhecido através do livro $\mathrm{V}$ das Ordenações Filipinas, conhecem-se várias passagens em que a Coroa portuguesa manifestou-se, limitando o direito dos senhores sobre seus escravos. ${ }^{24}$ Em 1642,

\footnotetext{
${ }^{20}$ Reis e Silva, Negociação e conflito, cit.

${ }^{21}$ Sidney Chalhoub. Visões da liberdade: uma história das últimas décadas da escravidão na Corte. São Paulo: Companhia das Letras, 1990.

${ }^{22}$ Chalhoub, id., p. 53.

${ }^{23}$ Lara, Campos da violência, cit., p. 58.

${ }^{24}$ Os castigos corporais eram comuns, permitidos por lei e com a aprovação da Igreja. As Ordenações Filipinas sancionavam a morte e a mutilação dos negros, como também o açoite. Segundo um regimento de 1633 o castigo deveria ser realizado por etapas.
} 
uma Carta Régia dirigida ao governador do Rio de Janeiro mandava que os senhores que castigassem desumanamente seus escravos fossem obrigados a vendê-los. ${ }^{25}$ Em 1688, duas Cartas Régias lembravam que os senhores só poderiam dar aquele moderado castigo que é permitido por lei e condenavam os maus-tratos e os castigos cruéis. Para evitar os abusos, a primeira delas ordenava que todas as denúncias de maus-tratos de senhores sobre cativos fossem averiguadas, inclusive quando feitas por escravos, e, quando confirmada a acusação, o senhor era obrigado a vendê-los. A segunda Carta Régia instruía que o governador do Rio de Janeiro tomasse considerações verbais breves sobre os casos excessivos de agressão, podendo esses senhores ser remetidos ao ouvidor através de citação em processo sumário. Eles seriam penalizados e obrigados a vender os escravos maltratados a outro senhor que os tratassem (se necessário) apenas com castigos moderados. ${ }^{26}$

No período imperial, a disputa entre o direito de punir dos senhores e o controle dessas ações pela justiça culminaria em ações mais efetivas com a promulgação da lei de 1871 . Dentre suas disposições, ela permitia aos escravos fazer denúncias contra o senhor por castigos desumanos e sevícias, prevendo ainda, como no período colonial, a obrigatoriedade da venda do escravo a outro senhor que não fosse cruel.

Para Hebe Maria Mattos, "parece mais lógico supor que a agressão violenta a senhores e especialmente a feitores tenha permanecido sempre uma possibilidade inerente à própria violência estrutural da dominação escravista, contida, entretanto, em limites suportáveis". ${ }^{27}$ Desse modo, a violência, embora fosse algo compreensível e aceito dentro do sistema escravista, devido à dureza de sua estrutura, precisava ser moderada a ponto de aprovada por todos, inclusive pelos próprios escravos. Dentro dessa lógica, o escravo José não reconheceu os castigos

\footnotetext{
${ }^{25}$ Segundo Kátia Mattoso, eram autorizadas, até 1824, as mutilações de escravos por meio de atos como marcar a ferro em brasa, esmagar os dedos, cortar orelhas e amputar parcialmente os pés. (Kátia de Queirós Mattoso. Ser escravo no Brasil. 3. ed. São Paulo: Brasiliense, 1990).

${ }^{26}$ Perdigão Malheiros. A escravidão no Brasil: ensaio histórico, jurídico, social. Petrópolis: Vozes, 1976. p. 645.

${ }^{27}$ Hebe Maria Mattos. Das cores do silêncio: os significados da liberdade no sudeste escravista. Rio de Janeiro: Nova Fronteira, 1998. p. 156.
}

aplicados a ele como justos, ademais, entendia que era um dever de seu senhor mantê-lo bem alimentado. É preciso compreender que o sistema trazia consigo

Mattos realizou um longo estudo com base em inventários post-mortem e documentos da Corte de Apelação do Rio de Janeiro. Em Das cores do silêncio, busca compreender os significados da liberdade no sudeste escravista, as expectativas e as ações de senhores e escravos em relação à liberdade no decorrer das transformações históricas, com especial atenção ao processo de desagregação do sistema escravista. Para a autora, embora a violência estivesse sempre presente no cotidiano cativo, havia também espaços para negociar as condições que aproximavam os escravos da liberdade. Mattos afirma ainda que as ações dos escravos foram fundamentais para o fim do cativeiro, pois desgastava aos poucos a legitimidade do sistema. A autora analisa também as relações entre o direito costumeiro e as leis positivas, demonstrando que o silêncio das leis não impediu que as disputas entre escravos e senhores fossem encaminhadas através da justiça, e que os escravos utilizavam o arcabouço jurídico para a defesa de seus direitos, encontrando, neste, formas de apresentar suas reivindicações. ${ }^{28}$

Em relação à alimentação oferecida aos escravos, Josephina Chaia e Luiz Lisanti, em estudo a respeito do Escravo na legislação brasileira, constataram que foi considerada mais importante a punição do cativo - ou ainda impostos, taxas e matrículas referentes a eles - do que suas necessidades básicas de higiene e alimentação. Dessa forma, poucos foram os textos que abordaram esse tema, embora se possa observar um que indica a proporção de alimentos que deveriam ser consumidos diariamente por um cativo: "Carne seca $3 / 4 \mathrm{de} \mathrm{lb}$, ou $1 \mathrm{lb}$ de carne fresca, Toucinho 1 onça. Feijão 1/120 de alqueire. Farinha 1/40 de dito" 29 .

\footnotetext{
28 Id. ibid.

${ }^{29}$ Josephina Chaia; Luís Lisant. "O escravo na legislação brasileira. (18081889)”. Revista de História, 35, (1974), p. 242. Com relação às medidas citadas, cabe aqui um esclarecimento das suas proporções. O alqueire é uma antiga medida muito utilizada com cereais. Tem a particularidade de poder ser usada como medida de capacidade, peso e superfície. Dependendo da região, pode equivaler de 10 a 14 litros de cereais (mais comumente a 13 litros), ou entre 11 e 15 quilos. Quando usada com líquidos, equivale a cerca de meio almude ou 6 canadas. Também é uma medida agrária que se originou da quantidade de terreno que se pode cobrir com 1 alqueire de semeadura, aproximadamente 100 braças (de 2,20 [metros? Palmos?])
} 
O total da porção que deveria ser ingerida por um escravo correspondia à média de 5.546 calorias diárias, porém carente em proteínas. Segundo Chaia e Lisanti, essa média não era cumprida pelos proprietários, dada a grande mortalidade entre os cativos e seus reclamos à justiça. Por outro lado, algumas pesquisas demonstram que maus-tratos infringidos aos cativos não resultavam na punição dos acusados mesmo perante a lei, principalmente se fossem referentes a senhores. ${ }^{30}$ Esse fato fica evidente na medida em que a maior parte das testemunhas do processo afirmam ter conhecimento de que os escravos da propriedade de Joaquim Pires Franco passavam fome, embora não soubessem sobre castigos excessivos.

Embora muitos direitos fossem adquiridos pelos escravos sobre o jugo do cativeiro através do direito costumeiro, como, por exemplo, ao pecúlio e à liberdade forçada, a decisão final sobre essas conquistas era sempre dada pelo senhor. Para Chalhoub, dessa maneira eram estabelecidos "laços morais que uniam senhores e escravos, sendo que esse 'elemento moral' era a única força capaz de deter os escravos, de confortá-los em sua "triste condição" 31

Durante quase todo o processo, o escravo José nega o assassinato, acusando Francisco de Barros e uma escrava de nome Isias (ambos encontravam-se próximos à fazenda Bananas, local em que o cadáver de Joaquim P. Franco havia sido encontrado). Evidentemente, José desejava livrar-se da pena de morte imposta pela justiça em punição a escravos que atentassem contra a vida de senhores e de seus familiares.

A confissão e a justificativa do crime, realizadas mais tarde por José, expressam o ato de ceder às provas e aos argumentos que o evidenciam como autor do crime. Esse ato pode ser representado também como uma possível manobra do curador, que ousou utilizar argumentos respaldados na lei "aplicada somente a pessoas juradas" para abrandar a

ou 15.625 palmos quadrados (cerce de $4,48 \mathrm{ha}$ ). A libra (lb) é uma medida de peso inglesa equivalente a cerca de 454 gramas. A onça, por sua vez, é uma medida de peso equivalente 1/16, ou em certos casos, 1/14 do arrátel (correspondia a 459 gramas). Eram aproximadamente 28,7 gramas. Disponível em: <http://www.ancruzeiros.pt/ancunidades.html>. Acesso em: 13 de novembro de 2011.

${ }^{30}$ Conforme os estudos de Ferreira, Crimes em Comum.

${ }^{31}$ Chalhoub, Visões da Liberdade (1988), p. 12. pena de José. ${ }^{32}$ Talvez compreendesse que a justificativa de abusos sofridos pelo senhor, de crueldade, pudessem ser aceitas pela justiça como "crime justificado". ${ }^{33}$ Entretanto, o castigo físico, segundo Chalhoub, sempre foi compreendido como esforço educativo. Se não fosse assim, jamais o teriam tolerado, nem senhores nem escravos.

O episódio do escravo indicado como réu do assassinato de seu senhor insere Guarapuava num cenário comum à historiografia. Certamente não reflete uma especificidade do cativeiro da região central do Paraná, mas mostra que essa região, embora ocupada e povoada tardiamente pelos padrões do sudeste brasileiro - foco das principais pesquisas sobre escravidão - , dotada de proprietários de poucas posses, acompanha os padrões gerais dos registros de criminalidade. Assim como na plantation, também aqui houve manifestações de cativos que nem sempre optaram por negociações com seus senhores, embora o caso em exame tenha mostrado indícios de uma possível tentativa de acordo, quando José, em seu depoimento, relata ter pedido a seu senhor que o vendesse, e, por não ter obtido êxito, parte para uma ação extrema.

O que observaremos no decorrer deste estudo é que os escravos buscaram de diversas maneiras sobreviver, da melhor forma possível, às armadilhas diárias consequentes das relações com seus senhores. Alguns agiam pensando em benefícios coletivos, outros lançando mão de negociações ou, ainda, agindo por motivos puramente pessoais. Em determinadas circunstâncias agiam sós ou com a ajuda e a cumplicidade de escravos; em outras

\footnotetext{
${ }^{32}$ A pena de galés perpétuas eram uma punição alternativa prevista no artigo 44 do código criminal do império. "A pena sujeita os réus a andarem com calceta no pé e corrente de ferro, juntos ou separados, e a empregarse nos trabalhos públicos da província onde tiver sido cometido o delito à disposição do governo". Código Criminal do Império do Brasil, comentado e anotado pelo conselheiro Vicente Alves de Paula Pessoa. 2. ed. (aumentada). Rio de Janeiro: Livraria Popular de A. da Cruz Coutinho, 1885, p. 115. Apud, Ferreira, Crimes em Comum, p. 126. Sobre esse assunto, Célia Maria Marinho de Azevedo desenvolve uma discussão em Crimes de Escravos subtítulo do terceiro Capítulo de sua obra Onda negra, medo branco: o negro no imaginário das elites - século XIX. Rio de Janeiro: Paz e Terra, 1987. ${ }^{33}$ Os crimes justificáveis, segundo o Código Penal brasileiro, artigo 14, parágrafo 1을 referiam-se apenas a pessoas juradas e eram sobrepostos quando o crime fosse realizado para evitar mal maior. Nesse caso devem intervir conjuntamente a favor do delinquente os seguintes requisitos: 1) certeza do mal que se propôs evitar; 2) falta absoluta de outros meios menos prejudiciais; 3) probabilidade da eficácia do que se empregou; 4) quando for feito em defesa da própria pessoa ou de seus direitos (este último item consta do parágrafo $2^{\circ}$ ). José Henrique Pierangelli. Códigos penais no Brasil: evolução histórica. São Paulo: Jalovi, 1980. p. 168.
} 
podiam contar com a colaboração de pessoas livres ou libertas. "O fato é que não foram o tempo todo vítimas ou heróis do sistema, mas na maior parte do tempo situaram-se numa zona de indefinições entre os dois pólos." ${ }^{34}$

\section{A "gaiola ideológica" da escravidão}

Se José não foi considerado vítima de Joaquim Pereira Franco porque figurou como réu condenado no processo criminal, tampouco Apolinário foi herói por ter interferido e poupado uma mulher das ameaças de violência de um homem chamado Bernardo porque, nesse caso, o escravo é apenas um figurante na cena do delito, sendo quase totalmente ignorado nos autos.

Bernardo estando neste distrito no lugar denominado Três Capões por ocasião de umas corridas de cavalo, na noite do dia 29 próximo passado mês de agosto, ali se alterando demasiadamente em conseqüência de embriagues, teve a imprudência não só de arrastar para o campo a uma mulher que o não queria acompanhar, pelo que lhes resultou algumas ofensas leves, mas também, por provocar com ameaças de briga a Apolinário, escravo que apareceu na dúvida tão somente para socorrer a dita mulher. ${ }^{35}$

Bernardo Pereira Ramos era um sujeito de 37 anos de idade, casado e lavrador. Na ocasião mencionada acima teria quebrado o "termo de bem viver", ao qual teria sido submetido três meses antes por "suas costumadas turbulências contra o sossego público" e por ter atentado contra a pessoa de Maria Madalena e seu esposo Manoel Antônio da Silva. ${ }^{36}$

Interessante é que o caso estava sendo acompanhado pelo delegado de polícia, tenente-coronel Idelfonso José Gonçalves de Andrade, réu de um processo no ano anterior, quando ainda era apenas

\footnotetext{
${ }^{34}$ Reis e Silva, Negociação e conflito, cit., p. 7.

${ }^{35}$ Centro de Documentação e Memória/Guarapuava, Unicentro. Juízo de Direito da Comarca de Guarapuava, processo criminal no 876.2.144, caixa no 05,1873 a 1876 , fls. 1 .

${ }^{36}$ Documentos processuais expedidos pela "polícia” do Império contra indivíduos encontrados fora de certo padrão de tolerância, exigido pelo Código de Processo Penal de 1832. "Estes processos não diziam respeito às infrações consideradas criminosas, eram essencialmente normalizadores da ordem pública, portanto podia-se fazer prender no caso da reincidência da sua assinatura." Eduardo Martins. Os pobres e os termos de bem viver: novas formas de controle social no Império do Brasil. Dissertação de mestrado em história. São Paulo, Universidade Estadual Paulista, [ano?]. p. 195.
}

um comerciante. Idelfonso, na ocasião, agrediu com uma faca seu administrador e feitor João Antunes Lima. O então feitor, que teria como parte de suas funções corrigir os possíveis desvios de comportamento dos escravos do patrão, agiu de forma contraditória e em defesa da escrava Quitéria, que estava recebendo castigos de Idelfonso. A escrava, segundo o depoimento encontrado no processo, havia falhado na tarefa de cuidar de outra "escrava velha" adoentada, que ficava sob sua responsabilidade quando se mudavam de uma fazenda para outra. ${ }^{37}$

João Antunes, cuja cor não é identificada no processo, e podendo ser ele livre, pobre ou mesmo liberto, ao afrontar o coronel Idelfonso para a defesa de um cativo, certamente possuía total compreensão de que estava desautorizando o poder máximo do sistema, e no mínimo sabia que seu emprego como camarada corria risco. ${ }^{38}$ Embora esse camarada pudesse desfrutar de benefícios cabíveis apenas a um superior do cativo, não recua nem fica anestesiado diante daquela atitude considerada por ele, João Antunes, crueldade do proprietário. O caso mostra ainda que, embora a tendência fosse de diferenciação entre libertos e livres em relação aos escravos pelo acúmulo de posses - tanto para garantir certo bem-estar quanto para reafirmar a distinção social de liberto - , também havia circunstâncias em que existiam proximidades entre livres e escravos. Em determinadas situações, como é o caso, indícios demonstram vínculos entre livres e cativos, o que leva à compreensão de que o feitor, por estar acima na hierarquia social e assim gozar de algumas regalias em relação aos cativos, se aproveitava para maltratá-los.

É possível observar também que mesmo sendo a escravidão um regime baseado na coerção e no condicionamento, havia possibilidades de os cativos estabelecerem relações mais amplas do que aquelas permeadas pelos supostos limites que não conseguiam neutralizar, como as relações com homens livres com os quais conviviam. Segundo Wissenbach, seria exatamente nessa "complexa rede social", aparentemente insignificante, que se formariam os

\footnotetext{
${ }^{37}$ Centro de Documentação e Memória/Guarapuava, Unicentro. Juízo de Direito da Comarca de Guarapuava, processo criminal no 872.2.103, caixa no 04,1872 .

${ }^{38}$ Nesse caso, o emprego de camarada correspondia à função de um trabalhador assalariado que realizava serviços avulsos nas fazendas. Tais funções podiam ser exercidas por agregados ou mesmo escravos da mesma propriedade.
} 
"elementos mais significativos para remir, em parte, sua escravização, dimensionando uma série de estratégias de independência no lastro dos vínculos sociais primários que acabavam por estabelecer". ${ }^{39}$

A convivência por tempo prolongado entre cativos e livres, não necessariamente senhores, mas agregados na mesma unidade produtora, possibilitava o estabelecimento de laços morais em suas relações. O número pouco expressivo de pessoas na rede de relacionamento das economias de subsistência desfavorecia a distinção entre eles e a formação de grupos isolados uns dos outros. A cumplicidade, ou senso de justiça, entre livres pobres e cativos, caracterizava-se em determinados momentos tão consistente que possibilitava oposições até mesmo em relações diretas entre senhores, ou entre senhores e cativos, mesmo que resultassem em violentos desfechos, como mostrou o caso acima. ${ }^{40}$

As relações entre livres e cativos é tema abordado em Senhores de poucos escravos, de Ricardo Alexandre Ferreira. Nesse trabalho, o autor enfoca a criminalidade como eixo condutor possível para a interpretação do cotidiano escravo no século XIX, através de autos criminais do período de 1830 a 1888 em Franca, região paulista em que o sistema escravista disseminava-se entre proprietários de poucas posses. Para o autor, apesar da violência e do controle exercido por senhores e autoridades, os escravos estabeleciam frequentes relações com a população de livres e libertos. Os "crimes" evidenciados na região eram desencadeados por dívidas e conflitos amorosos, dentre outras motivações que muitas vezes aproximavam mais os cativos da população livre do que do mundo senhorial. ${ }^{41}$

Portanto, analisando os dados apresentados no processo de Idelfonso é possível deduzir um contato harmonioso e complexo entre livres pobres e cativos

\footnotetext{
${ }^{39}$ Wissenbach, Sonhos africanos, vivências ladinas, cit., p. 110.

${ }^{40}$ Os modelos de estratificação social devem ser pensados de acordo com a estrutura econômica e social de cada região. Porém é possível observar que nas regiões de subsistência, onde não há uma economia dinâmica como na plantation, que atrai inúmeros indivíduos de ofícios especializados como carpinteiro, alfaiate, ferreiro, pedreiro etc., ocorre uma grande carência profissional. Sendo assim, em Guarapuava um mesmo indivíduo podia exercer vários cargos ocupacionais, como é o caso de João Antunes. Sobre esse assunto, ver Kátia M. de Q. Mattoso. Bahia, século XIX: uma província no Império. Rio de Janeiro: Nova Fronteira, 1992; Rafael de B. Marquese. Feitores do corpo, missionários da mente: senhores, letrados e controle dos escravos nas Américas, 1660-1860. São Paulo: Companhia das Letras, 2004.

${ }^{41}$ Ricardo Alexandre Ferreira. Senhores de poucos escravos: cativeiro e criminalidade num ambiente rural (1830-1888). São Paulo: Unesp, 1995.
}

no cenário da escravidão. É lúcido supor a relação de afeto entre a escrava Quitéria e o administrador da fazenda, tendo em vista que este não reagiu com naturalidade ao castigo aplicado pelo proprietário. $\mathrm{O}$ fato fica ainda mais evidente se considerarmos que, mesmo não sendo a atitude parte da índole violenta do proprietário, era do seu conhecimento que o ato intrépido acarretaria sérias consequências, embora talvez nem houvesse sonhado com a gravidade.

Eugene Genovese mostra que nos Estados Unidos eram comuns os desentendimentos entre senhores e administradores, e que aqueles os demitiam por diversos motivos, dentre os quais a excessiva generosidade com os cativos ou então a excessiva dureza com eles. Para o autor, "aos administradores que perdiam o emprego devido à leniência excessiva incluíam-se os que simplesmente se furtavam ao dever, de modo que a acusação de leniência nada nos informa a respeito de suas atitudes em relação aos escravos". ${ }^{42}$ Todavia, o que observamos claramente na relação entre a escrava Quitéria e o administrador João Antunes Lima, que também exercia a função de camarada e feitor, é uma proximidade cotidiana decorrente da identificação social por achar-se João tão próximo da condição da escrava. Em muitos casos, os administradores correspondiam à reputação de classe dos livres pobres, mesmo sendo libertos, fator que de certo modo aproximava esses indivíduos dos escravos.

Para Genovese, escravos, libertos e livres que viviam muito próximos nos sítios tinham um relacionamento diferenciado daquele da plantation, e o relacionamento que havia entre eles levou a uma generalizada reputação de "tratamento melhor". Como pudemos observar na análise anterior de José e Joaquim Pires Franco, ou mesmo nesse caso referente ao tenente-coronel, a existência de boas relações não é a regra entre senhores e escravos nas pequenas unidades produtoras, o que contradiz as ideias de haver benevolência da parte desses proprietários por manterem uma vida em comum mais próxima, e a ideia de os escravos agirem passivamente com seus senhores por conta desse aparente tratamento melhor.

Stuart Schwartz, ao analisar o trabalho de Peter Eisenberg sobre a força de trabalho nos engenhos

\footnotetext{
${ }^{42}$ Eugene Dominick Genovese. A terra prometida: o mundo que os escravos criaram. Rio de Janeiro: Paz e Terra; Brasília, DF: CNPq, 1988. p. 27.
} 
da Bahia, acrescenta que, embora os lavradores livres compusessem categoriais sociais distintas com diferentes status e condição jurídica em relação a determinados tipos de trabalhos praticados por escravos e livres, os senhores de engenho muitas vezes não os diferenciavam ou separavam, porque os consideravam "dois pontos de um continuum, cada qual com suas vantagens e problemas". ${ }^{43}$

$\mathrm{O}$ ato de agressão no camarada João Antunes pelo coronel Idelfonso ocorrera em 1856, quando este ainda era comerciante. Tendo resolvido o caso nos "limites" de sua propriedade, e com a morte desse camarada numa cidade do Rio Grande do Sul em 1872, o então delegado de polícia da comarca de Guarapuava, Antônio José da Piedade, abre inquérito para investigar a participação de Idelfonso nessa morte. Interessante é que um ano após ter esclarecido o caso e provado sua inocência, Idelfonso assume a delegacia de polícia como delegado. Se esse acontecimento teve ou não peso na aquisição do cargo de delegado, não é possível saber. O fato é que no século XIX os coronéis desfrutavam de grandes poderes locais. ${ }^{44}$

O coronel Idelfonso, delegado, responsável pelo termo de normalização da ordem pública, teve atitudes excessivas em relação a seu camarada João Antunes, que contrariou suas expectativas, bem como demonstrou intolerância com o erro de sua escrava Quitéria. Isso poderia levar à indução de uma leitura duvidosa de suas mediações policiais, podendo interferir no tratamento dado ao escravo Apolinário na mediação do "termo de bem viver". Entretanto, mesmo que isso fosse aceitável, Apolinário não seria considerado suspeito do crime ou excluído da lista de testemunhas pelo delegado por conta de sua suposta índole duvidosa, até porque a própria lei se encarregaria desse detalhe. ${ }^{45}$

O artigo VI da lei no 40, parágrafo 3 da seção

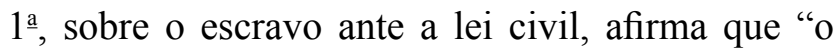

\footnotetext{
${ }^{43}$ Stuart B. Schwartz. Segredos internos: engenhos e escravos na sociedade colonial, 1550-1835. São Paulo: Companhia das Letras, 1988. p. 215.

${ }^{44}$ A patente de "coronel" correspondia a um comando municipal ou regional criado pela Guarda Nacional, em 1831, para a defesa das instituições cujo titular raramente deixava de ser proprietário rural com grande poder econômico, social e político. As patentes traduziam prestígio real nas sociedades organizadas sobre as bases do escravismo, atribuindo grandes poderes de interferência na região como advogados de interesses locais. (Victor Nunes Leal, Coronelismo: enxada e voto. São Paulo: Omega, 1975.)

${ }^{45}$ Ferreira em Costumes em comum, o "simples fato de um cativo estar no local do crime era suficiente para que fosse considerado como suspeito". p. 137.
}

escravo não podia ser testemunha. Exceto: $1^{\circ}$ se era tido geralmente por livre; $2^{\circ}$ quando a verdade se não podia descobrir por outro modo; $3^{\circ}$ quando submetido à tortura, nos casos em que era permitido". ${ }^{46}$ E achando-se o delegado na mesma noite e lugar e no flagrante prendendo Bernardo, o testemunho do escravo Apolinário torna-se desnecessário, mesmo que tenha sido ele uma testemunha ocular importantíssima para o detalhamento do caso. E quanto às ações que poderiam pôr em dúvida o trabalho do atual delegado, a justiça e a sociedade oitocentistas o haviam declarado inocente, e "qualquer tentativa tímida de questionamento de seus atos teriam como resposta uma firme e inabalável argumentação baseada na legislação em vigor". ${ }^{47}$

Para A. J. R. Russell-Wood, embora houvesse leis que garantissem aos escravos alimentação, abrigo e descanso adequado, além de casamento, e que concediam proteção legal contra excessos nas punições, não lhes era dado direitos legais que pudessem perturbar o status quo dos senhores. Portanto, não era permitido que testemunhassem como prova contra seus senhores, pois estes poderiam se tornar alvos de constates inquéritos. ${ }^{48}$

O auto do "termo de bem viver" abre outra possibilidade de análise. Dando enfoque ao fato de que Apolinário, escravo que havia presenciado e interferido na agressão de uma mulher por Bernardo, encontrava-se durante a noite em corridas de cavalos (lugar considerado improvável por pesquisadores que viam nas correntes a única forma de controlar os cativos), sem a presença de seu senhor, é possível concluir, como já ocorre há muito na historiografia brasileira, que a ideia de cativeiro no sentido restrito de manutenção do escravo nas correntes, fechado, sempre sob os olhos e comando de seu senhor, é inaceitável, pois a escravidão constituiu-se em um quadro complexo que não cabe em explicações fixas, dualistas e generalizantes.

Silvia Lara acredita que não se fazia necessário um círculo de comandos e correntes, uma vez que essa condição era mais uma questão de consciência internalizada pelos escravos e havia, segundo a autora, todo um universo que se encarregava dessa

\footnotetext{
${ }^{46}$ Perdigão Malheiros. A escravidão no Brasil, cit., p. 67.

${ }^{47}$ Ivan de Andrade Vellasco. As seduções da ordem, cit., p. 118.

${ }^{48}$ Russel-Wood, A. J. R, Escravos e libertos no Brasil colonial. Ttrad. de Maria Beatriz Medina. Rio de Janeiro: Civilização Brasileira, 2005. p. 25.
} 
atividade, como as relações físicas e pessoais, que serviam para reafirmar suas condições. ${ }^{49} \mathrm{Ou}$ seja, os africanos e seus descendentes tornavam-se escravos com a conscientização de todo o relevo inerente ao ser escravo, e esse juízo era promovido, em parte, pela inserção desses indivíduos em ambientes que lhes tolhiam a liberdade.

Guarapuava, por constituir, em 1873, uma região ainda pouco povoada, facilitava atitudes coercitivas da população livre contra os cativos, principalmente porque os proprietários, quando não mantinham relações próximas, conheciam-se eventualmente e também às suas posses. Nesse sentido, Ricardo Ferreira observou que, em Franca, os cativos circulavam por todos os lugares da comarca, vigiados apenas pelas autoridades e os indivíduos locais que pertenciam ao círculo de conhecimento e amizade dos senhores. Podemos afirmar ser esse o caso de Apolinário, uma vez que se encontrava no local, além de pessoas que prestigiavam o evento da corrida de cavalos, a autoridade policial, na pessoa de Idelfonso Gonçalves de Andrade, delegado de polícia de Guarapuava.

Para Reis, a forma como estava estruturada a sociedade, com valores e percepções de realidade, constituíam o que chamou "paradigma ideológico colonial e sob este a sociedade se identifica enquanto gaiola, tornando supérfluo o uso de correntes ao pé de cada passarinho". ${ }^{50}$ Idelfonso mostra que a gaiola social talvez fosse mais eficiente quando não se podia valer do direito de usar os benefícios de possuir um bom feitor para que este pudesse repreender e castigar os escravos na sua ausência. $\mathrm{O}$ bom feitor era aquele que devia ter atitude "bem ordenada e dependente não absoluta, delegada e submissa à autoridade senhorial", características inexistentes em João Antunes, como mostra a análise. ${ }^{51}$

Considero que os dois casos apresentados - referentes ao escravo Apolinário como "testemunha" da violência contra uma mulher livre e, outro, da escrava Quitéria defendida por um feitor - possibilitam visualizar uma proximidade conflituosa e às vezes contraditória nas relações entre livres e escravos, que todavia não é estranha

\footnotetext{
${ }^{49}$ Lara, Campos da violência, cit., p. 236.

${ }^{50}$ Reis e Silva, Negociação e conflito, cit., p. 67.

${ }^{51}$ Lara, Campos da violência, cit., p. 165.
}

e incompreensível às análises historiográficas pós-década de 1980. Procurou-se evidenciar aqui a complexa dinâmica do cotidiano escravista, que ultrapassava os supostos limites e barreiras estabelecidos pelos senhores e pelo aparato judicial do período.

A escravidão africana no Brasil é um tema de estudo intrigante, que tem atraído inúmeros historiadores ao longo dos anos. Tal interesse norteou os pesquisadores na busca de alternativas teóricas e empíricas. O presente estudo nasceu justamente da confluência entre a historiografia da escravidão e o interesse dos historiadores, nas últimas décadas, pela documentação remanescente da polícia e da justiça criminal. Em conjunto, tais produções auxiliaram a elaboração de novas hipóteses de pesquisa a respeito dos momentos de tensão vividos por senhores e escravos no cotidiano.

Tomando por base esses apontamentos historiográficos, o presente artigo buscou compreender alguns aspectos do cotidiano de escravos na região de Guarapuava por meio da análise de documentos remanescentes da polícia e da justiça criminal produzidos na região durante a segunda metade do século XIX.

É possível perceber, ao longo desta narrativa, que a escravidão africana interpretada com base nas investigações de autos policiais e processos criminais possibilitam inúmeras oportunidades de análise do cotidiano escravista. Menosprezar a justiça, mesmo que esta tenha mecanismos próprios para definir a "verdade", é fechar os olhos para parte da história do cativo, talvez perceptível apenas nessas fontes.

Ao considerar tais documentos e a historiografia desenvolvida sobre a escravidão, é possível afirmar que as migrações iniciadas em 1809 possibilitam mais que desenvolvimento econômico para a vasta área onde se construiu o município de Guarapuava. Os indivíduos que ali se estabeleceram carregavam consigo costumes e culturas de diversas localidades, como do primeiro e do segundo planalto paranaense, e do sudeste brasileiro. ${ }^{52} \mathrm{O}$ cativeiro fazia parte desses costumes, mas ganhou na região

\footnotetext{
52 "A ação colonizadora empreendida a partir do Planalto Paulista, representou fio condutor que determinou a extensão dos arranjos possíveis naquele quadro de organização das populações." Rosângela Ferreira Leite, Nos limites da colonização: ocupação territorial, organização econômica e populações livres pobres (Guarapuava, 1808-1878). Tese de doutorado em História. São Paulo: Universidade de São Paulo, 2006. p. 21.
} 
características próprias. Nesse contexto ímpar, José, Joana e Apolinário foram três personagens que, sob o jugo do cativeiro, enfrentaram dilemas e optaram por caminhos distintos que por fim os levaram à justiça. Diante da encruzilhada, e oscilantes entre se submeter às regras do trabalho e sobreviver pacificamente, sem questionar o poder senhorial, ou então de partir para atitudes mais violentas de protesto como negação do sistema, os cativos aqui estudados tomaram diferentes atitudes: de indignação pessoal e crime contra o senhor, conquista do administrador e feitor, defesa de pessoas livres. Atitudes baseadas nos recursos disponíveis da ocasião e do local no qual se encontravam, de certa maneira, demonstraram claras estratégias de dilatação da então limitada "liberdade" cotidiana proposta naquelas ocasiões.

Afirmar que os escravos que ali residiam não possuíam conhecimento daquilo que constituía o sistema escravista, e por isso seus atos são expressões frívolas, como foi o caso de José, seria uma conclusão simplista. Ademais, como já apontaram as inúmeras pesquisas acerca da escravidão no Brasil, o sistema escravista possui um caráter multifacetado; portanto, é inadmissível reduzi-lo a modelos explicativos baseados em abordagens historiográficas específicas, como as de regiões de subsistência.

Este estudo revela, a partir da apresentação dos atores sociais envolvidos no cotidiano das regiões de subsistência de Guarapuava, que, assim como nas plantations, eles não estavam alheios aos pressupostos fundamentais das relações escravistas. De qualquer forma, considero que a realização dos propósitos de posicionar-se no cotidiano do cativeiro incorporava questões bastante complexas. Sem dúvida alguma, cada região brasileira produziu de modo particular suas regras sociais e suas oportunidades, as quais, num processo contínuo, eram remodeladas pelos cativos, possibilitando novos relacionamentos com seus senhores e outros livres presentes na dinâmica dessas economias.

Os conflitos encontrados em Guarapuava e estudados neste artigo não deixaram de apresentar características comuns a outras regiões, como os apontados nos estudos de Alexandre Ferreira (o assassinato de senhores), tampouco deixou de apresentar suas irregularidades, suas peculiaridades próprias e distintas, como é o caso em que concerne à forma, ao local e aos motivos da prática de tal ato de homicídio.

As teorias, as metodologias e o enfoque dado às evidências neste estudo destacaram o caráter às vezes conflituoso, e às vezes consensual das relações escravistas, resultado da propriedade peculiar das regras sociais, culturais, políticas e econômicas do período escravista na região de Guarapuava.

\section{REFERÊNCIAS BIBLIOGRÁFICAS:}

CERTEAU, Michel de. A escrita da história. 2. ed. Rio de Janeiro: Forense, 2002.

CHALHOUB, Sidney. Visões da liberdade: uma história das últimas décadas da escravidão na Corte. São Paulo: Companhia das Letras, 1990.

FERREIRA, Ricardo Alexandre. Crimes em comum: escravidão e liberdade no extremo nordeste da província de São Paulo (Franca, 1830-1888). Tese de doutorado em história. Franca: Faculdade de História, Direito e Serviço Social, 2006.

Senhores de poucos escravos: cativeiro e criminalidade num ambiente rural (1830-1888). São Paulo: Unesp, 1995.

FERREIRA LEITE, Rosângela. Nos limites da colonização: ocupação territorial, organização econômica e populações livres pobres (Guarapuava, 1808-1878). Tese de doutorado em história. São Paulo: Universidade de São Paulo, 2006.

FRANCO NETTO, Fernando. Povoamento, população e escravidão no século XIX. Guarapuava: Unicentro, 2007.

GENOVESE, Eugene Dominick. A terra prometida: o mundo que os escravos criaram. Rio de Janeiro: Paz e Terra; Brasília, DF: CNPq, 1988.

GUTIÉREZ, Horácio. "Donos de terras e escravos no Paraná: padrões e hierarquias nas primeiras décadas do século XIX”. História, São Paulo, 25, (2006).

JESUS, Alisson Luiz Freitas de. No sertão das Minas: escravidão, violência e liberdade (1830-1888). São Paulo: Annablume; Belo Horizonte: Fapemig, 2007.

LARA, Silvia Hunold. Campos da violência: escravos e senhores na capitania do Rio de Janeiro, 1750-1808. Rio de Janeiro: Paz e Terra, 1988.

LEAL, Victor Nunes. Coronelismo: enxada e voto. São Paulo: Omega, 1975.

LIBBY, Douglas Cole; FRANK, Zephyr. "Voltando aos registros paróquias de Minas colonial: etnicidade em São José do Rio das Mortes, 1780-1810. Revista Brasileira de História, v. 29, no 58 (2009), p. 383-415. 
MACHADO, Maria Helena P. T. Crime e escravidão: trabalho, luta e resistência nas lavouras paulistas (18301888). São Paulo: Brasiliense, 1987.

MATTOSO, Kátia de Queirós. Ser escravo no Brasil. 3. ed. São Paulo: Brasiliense, 1990.

MALHEIROS, Perdigão. A escravidão no Brasil: ensaio histórico, jurídico, social. Petrópolis: Vozes, 1976.

MARTINS, Eduardo. Os pobres e os termos de bem viver: novas formas de controle social no Império do Brasil. Dissertação de mestrado em história. São Paulo: Universidade Estadual Paulista, 2000.

MATTOS, Hebe Maria. Das cores do silêncio: os significados da liberdade no sudeste escravista. Rio de Janeiro: Nova Fronteira, 1998.

PIERANGELLI, José Henrique. Códigos Penais no Brasil: evolução histórica. São Paulo: Jalovi, 1980.

PIRES, Maria de Fátima Novaes. O crime na cor: escravos e forros no alto sertão da Bahia (1830-1888). São Paulo: Annablume/Fapesp, 2003.

REIS, João José; SILVA, Eduardo. Negociação e conflito: a resistência negra no Brasil escravista. São Paulo: Companhia das Letras, 1996.

RUSSEL-WOOD, A. J. R. Escravos e libertos no Brasil colonial. Trad. de Maria Beatriz Medina. Rio de Janeiro: Civilização Brasileira, 2005.

SCHWARTZ, Stuart B. Segredos internos: engenhos e escravos na sociedade colonial, 1550-1835. São Paulo: Companhia das Letras, 1988.

THOMPSON, Edward Palmer. Senhores e caçadores: a origem da Lei Negra. Rio de Janeiro: Paz e Terra, 1987.

VELLASCO, Ivan de Andrade. As seduções da ordem: violência, criminalidade e administração da justiça; Minas Gerais, século 19. São Paulo: Edusc, 2004.

WISSENBACH, Maria Cristina Cortez. Sonhos africanos, vivências ladinas: escravos e forros em São Paulo (18501880). São Paulo: Hucitec, 1998.

\section{Agradecimentos}

Às orientações do Prof. Dr. Ricardo Alexandre Ferreira e às sugestões realizadas pela $\operatorname{Prof}^{\mathrm{a}} \operatorname{Dr}^{\mathrm{a}}-$ Karina A. Anhezini e Prof. Ms. Raphael Nicolleti Sebrian.

Artigo Submetido: 11/02/2013

Artigo Aprovado:16/06/2013 